\title{
Understanding the U.S. Bioeconomy: A New Definition and Landscape
}

\author{
George B. Frisvold ${ }^{1}$ * , Steven M. Moss ${ }^{2}$, Andrea Hodgson ${ }^{2}$ and Mary E. Maxon ${ }^{3}$ \\ 1 Department of Agricultural \& Resource Economics, University of Arizona, Tucson, AZ 85721, USA \\ 2 National Academies of Science, Engineering, and Medicine, Washington, DC 20001, USA; \\ SMoss@nas.edu (S.M.M.); AHodgson@nas.edu (A.H.) \\ 3 Lawrence Berkeley National Laboratory, Berkeley, CA 94720, USA; memaxon@lbl.gov \\ * Correspondence: frisvold@ag.arizona.edu
}

Citation: Frisvold, G.B.; Moss, S.M.; Hodgson, A.; Maxon, M.E. Understanding the U.S. Bioeconomy: A New Definition and Landscape. Sustainability 2021, 13, 1627. https:// doi.org/10.3390/su13041627

Academic Editor: Justus

H.H. Wesseler

Received: 1 December 2020

Accepted: 20 January 2021

Published: 3 February 2021

Publisher's Note: MDPI stays neutral with regard to jurisdictional claims in published maps and institutional affiliations.

Copyright: (c) 2021 by the authors. Licensee MDPI, Basel, Switzerland. This article is an open access article distributed under the terms and conditions of the Creative Commons Attribution (CC BY) license (https:/ / creativecommons.org/licenses/by/ $4.0 /)$.

\begin{abstract}
This article provides an overview of the U.S. bioeconomy, discussing how its definition has evolved and been formalized over time. The first attempts to conceptualize and define the U.S. bioeconomy began in the early 1990s. This was followed by a series of government and private efforts to develop methods to understand and evaluate it and to develop programs to promote it. These efforts culminated in the 2020 release of the National Academies of Science, Engineering, and Medicine (NASEM), Safeguarding the Bioeconomy report. The report recommended a formal definition of the U.S. bioeconomy, providing the rationale for that particular definition in the U.S. context. Formally adopting a comprehensive definition of the U.S. bioeconomy would enable the U.S. government to better assess the bioeconomy's current state, to develop strategies to support its growth, and to promote strategies to safeguard it. Along with this recommendation, the NASEM Safeguarding report also discussed defining the "bioeconomy landscape," which involves more precise determination and quantification of which economic activities are part of and external to the U.S. economy. Defining this landscape could guide metric development and data collection needed to track the bioeconomy's growth, conduct economic assessments, and enable policy makers to keep abreast of advances that could potentially pose new national or economic security challenges. The report also includes an analysis of the broad range national bioeconomy strategies, identification of the four drivers of the U.S. bioeconomy, and the first of its kind, comprehensive estimate of the size and scope of the U.S. bioeconomy of USD 959B (valued in 2016 constant USD ).
\end{abstract}

Keywords: bioeconomy; biotechnology; life science; innovation; R\&D; biological resources; science policy

\section{Introduction}

Advances in information and computing sciences, along with the integration of engineering principles, has fundamentally transformed the life sciences and biotechnology in the last 50 years. Breakthroughs, such as the ability to read genetic code, to edit an organism's genome, and to create organisms with entirely synthetic genomes, have changed how research is done and the products that innovators can be create. The term "bioeconomy" encompasses economic activity related to life sciences research. Some products of the bioeconomy include microorganisms acting as environmental biosensors, fabrics made from biosynthetic spider silk, chemicals made though biosynthetic pathways instead of solely petrochemical synthesis (such as 1,3-propanediol), and novel foods and food additives made from yeast or bacteria. The U.S. bioeconomy offers means of developing innovative products, with benefits such as reduced carbon emissions and improved health care applications. While the bioeconomy has opened new opportunities for innovation, job creation, and economic growth, it has brought vulnerabilities and concerns.

In 2019, at the request of the U.S. Office of the Director of National Intelligence, the U.S. National Academies of Science, Engineering, and Medicine (NASEM) convened a 
committee of experts to evaluate the scope and the economic value of the U.S. bioeconomy. The committee was also tasked with identifying potential national security and economic risks to the U.S. bioeconomy. This included identifying policy gaps, determining means of tracking advances and developments in the bioeconomy, and considering cybersecurity solutions to protect data and other bioeconomy outputs. The work of the committee culminated in a NASEM consensus study report, Safeguarding the Bioeconomy (the Safeguarding report) [1].

The U.S. bioeconomy is a multifaceted set of enterprises, spanning diverse scientific disciplines and sectors and including a diverse and ever-changing set of stakeholders. A starting point for basic life sciences research is public investment to train scientists. These scientists work in universities and federal research institutions in addition to research and development $(R \& D)$ departments of corporations. These traditional research institutions have also encouraged local innovation ecosystems. This has drawn in new stakeholders, -small businesses and partnerships with larger industrial companies- which now include start-up companies, incubator spaces, and citizen-science labs. In turn, networks of firms providing materials, tools, expertise, and other services have also grown to support these businesses. Computing and information sciences, including machine learning, have made it possible to analyze and use biological data in new ways, and have accelerated the reach of the bioeconomy. New engineering applications have enabled automation and highthroughput experimentation. This has further accelerated the growth of the bioeconomy.

There is currently no broad consensus among countries, organizations, or academics about a precise definition of the bioeconomy. This has led to different interpretations of what activities lie within the scope of the bioeconomy. A fundamental challenge in attempting to define the bioeconomy is that its activities span many sectors and scientific disciplines [2]. Consequently, this often involves combining subsets of traditional sectors that are measured in systems of national income accounts in novel (and non-uniform ways). Definitions have often arisen in response to individual country's' economic priorities, biological resource base, technological capacity, and regulatory approaches to deployment of biotechnology.

The U.S. National Bioeconomy Blueprint first articulated a definition of the U.S. bioeconomy in 2012 [3]. Given significant scientific advances that have occurred since then, it is worthwhile to reassess this definition. A new, comprehensive definition would help the U.S. government to better assess the current state of the U.S. bioeconomy and to develop strategies to foster its sustainable growth. A practical definition could also help guide data collection and metric development necessary to track the bioeconomy's growth and to conduct economic assessments. It could also enable policy makers to monitor advances that could potentially pose new challenges to national or economic security. The NASEM Safeguarding report developed a definition of the bioeconomy that does not limit the scope of the U.S. bioeconomy to particular technologies, processes, or economic sectors. Rather, it recognizing that a definition needs to be flexible enough to allow for the future inclusion of new developments.

This article examines how the definition of the U.S. bioeconomy has evolved to become more formalized over time. It discusses early attempts, in the 1990s, to conceptualize and define the bioeconomy. The article next provides an overview of government and private industry efforts to understand, assess, and promote the U.S. bioeconomy. The piece culminates by discussion of the bioeconomy definition recommended in the NASEM Safeguarding report. Different countries have adopted different definitions of the bioeconomy. These have been influenced by their scientific capacity as well as their biological resource base. These have also been conditioned by their environmental, science, and technology policies, particularly, biotechnology policies. The United States is no exception to these influential factors. We emphasize that this article is a positive analysis. We discuss how definitions of U.S. bioeconomy have come about and what recommendations in the Safeguarding report are. The article summarizes the pros and cons of different approached to define the bioeconomy in the U.S. context. It does not make any special 
claims about how other entities should do so. While it briefly compares the U.S. approach with those of other countries and regions, it is not meant to be an exhaustive comparative analysis. North American studies have taken distinctly different approaches to defining the bioeconomy landscape (which economic activities are to be considered within and outside of the bioeconomy) than approaches taken in EU countries, Japan, and other regions. Earlier North American approaches have tended to adopt narrower definitions of the bioeconomy landscape, while other regions have tended to define the bioeconomy more broadly. This is a rather broad characterization and there are counterexamples of North American studies taking a more inclusive approach to certain activities. We discuss the advantages and disadvantages of adopting broader versus narrower approaches. There has also been recent movements towards convergence in approaches. This will hopefully encourage greater international research and policy collaboration on measuring and promoting the bioeconomy.

\section{Early U.S. Perspectives on "the Bioeconomy"}

Over the past two decades, interest in the concept of "the bioeconomy"- as a topic of research and as a focus of economic, technology, and national security policy-has grown rapidly. The number of research publications referring to "the bioeconomy" (or to closely related terms) has grown sharply beginning in the mid-2000's (Figure 1) [4-7]. As of 2018, more than 40 countries had developed formal strategies to promote their bioeconomies [8]. By 2020, nearly 60 countries were doing so [9]. In addition, efforts are underway to harmonize measurements of the bioeconomy and its contribution to the overall economy across countries [10-12].

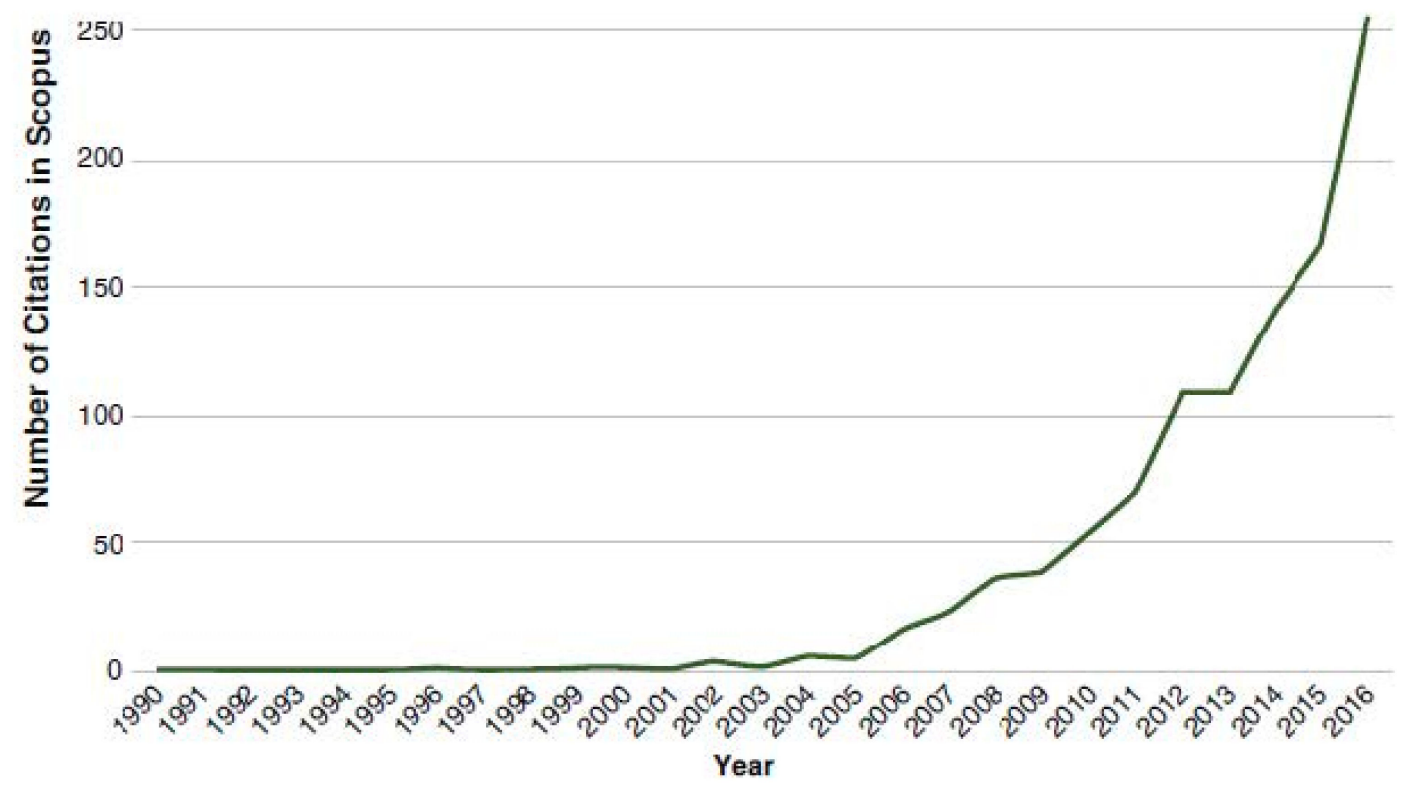

Figure 1. Number of publications listed in Scopus with "bioeconomy", "bio-economy", "biobased economy", or "bio-based economy" included in their titles, abstracts, or keywords [5].

What accounts for this recent surge in research interest and policy activity related to the bioeconomy? Humans have, after all, been growing crops, raising livestock, brewing beer, and using wood for building material and fuel for millennia. Humans have been gathering biological materials to test their nutritional and medicinal potential for even longer. Using biological resources remains a fundamental part of modern economies. 
Agriculture, forestry, and fisheries (in addition to mining) are referred to as the "primary sectors" of national economies.

Three factors have contributed to this interest in the bioeconomy. First, advances in biological sciences and biotechnology offer promising new commercial applications, in addition to new ways of supplying existing products. Developments in DNA sequencing, genetic engineering, and high-throughput molecular operations facilitated by robotics have "transformed the practice and potential of biological research" [3] p. 7. Major advances in engineering biology have included gene-editing approaches involving meganucleases, TALENs (transcription activator-like nucleases), zinc fingers, and CRISPR (clustered regularly interspaced short palindromic repeats) technology. Consequently, biotechnology has become a new area of international technological and economic competition [3,13-16]. Secondly, in many countries, the substitution of renewable biological resources for exhaustible fossil fuels to produce electricity, fuel, and chemical-based manufactured goods has been promoted to further various policy objectives $[8,17-19]$. These include climate change mitigation, energy self-sufficiency, rural economic development, and export promotion. Third, biodiversity and genetic resources have been viewed as inputs critical to the discovery and production of new pharmaceuticals and other bio-based products [20-27]. Genetic resources serve as a source of materials and as blueprints for the design of new commercial compounds [28].

Dr. Bernadine Healy, as director of the U.S. National Institutes of Health (NIH), used the specific term "the bioeconomy" in speeches dating back to 1992 [29-31]. In her 1994 commencement address at Vassar College, Healy [32] (p. 13) noted:

"A revolution in the life sciences will also go way beyond medicine into agriculture, chemical production, environmental sciences, and microelectronics. Biotechnology will be creating jobs that we don't even have names for yet. And they will be high-paying, high-demand jobs-and intellectually satisfying ones. New industries will emerge that will be a growing source of national economic strength and world leadership. Some have gone so far as to suggest that the twenty-first century will be based on a bioeconomy."

Juan Enriquez and Rodrigo Martinez have been credited with using the term "bioeconomy" at a scientific conference in 1997 [5,33-36]. In a 1998 Science article, "Genomics and the World's Economy," Enriquez, while not using the term "bioeconomy" specifically, emphasizes the scientific, technological, and economic implications of innovations in genomics that allowed for the study, design, and construction of economically important molecules [37].

Enriquez's article emphasized the important economic implications of advances in genomics [37]. Boundaries between the agribusiness, pharmaceutical, and chemical industries were beginning to blur as the potential for complementary technological applications was spurring corporate mergers and acquisitions. According to Enriquez, "The objective of the life science company is no longer to generate breakthroughs in a single area such as medicine, chemicals, or food, but to become a dominant player in all of these [37]." Indeed, companies grounded in chemical, pharmaceutical, and agricultural production merged, reorganized, and acquired seed companies (along with their crop germplasm resources), expanding into the development and sale of genetically modified crops [38-42]. These changes in scientific and business models, Enriquez further argued, would transform the energy sector, as plant-based energy sources would begin to substitute for fossil fuels. Enriquez heralded the rise "of a new economic sector, the life sciences [37]."

U.S. agriculture, over the last 25 years, has illustrated the very transformations Enriquez envisioned. There have been significant shifts in both how crops are used and how new crop varieties are developed. The U.S. energy sector has shifted toward greater use plant-based fuels, just as Enriquez envisioned. More than a third of today's U.S corn and soybean crop is used for fuel. The United States is now the world's leading producer of biofuels, followed by Brazil and the European Union (EU) [43]. Genetically modified crops now account for roughly half of all U.S. crop sales [1]. 


\section{Defining the U.S. Bioeconomy: Recent Developments}

Several events led to greater examination of the U.S. bioeconomy. In response to The Great Recession, interest turned toward technology policy as one means of stimulating economic recovery. First, in 2009, the NASEM issued A New Biology for the 21st Century [44], which examined critical intersections of biotechnology and other scientific disciplines, including computer science and engineering and discussed the role of biotechnology in addressing a variety of human health, food and nutrition, energy, and the environmental needs (NRC, 2009). While focusing on social benefits, the report also identified critical linkages between biological innovation and economic benefits. Next, in 2010, the White House Office of Science and Technology Policy (OSTP) and the Office of Management and Budget (OMB) issued a joint guidance memorandum on science and technology priorities for the fiscal year (FY) 2012 budget. The memorandum directed federal agencies to place priority on efforts to promote job creation and sustainable economic growth. Agencies were to "support research to establish the foundations for a 21st century bio-economy" in areas where "advances in biotechnology and improvements in our ability to design biological systems have the potential to address critical national needs in agriculture, energy, health and the environment [45]." Notably, the memorandum highlighted biotechnology as a key feature of the U.S. bioeconomy. This reflected the strengths of the U.S. public and private R\&D programs that focused on cutting-edge engineering biology and big data approaches to apply biological research to meet national challenges.

Another policy goal was to stimulate economic growth and enable entrepreneurs to create new companies and new jobs by reforming the patent system. This resulted in the America Invents Act of 2011, which sought to lower barriers hindering biotechnology, medical devices, and advanced manufacturing industries. The act provided a fast-track patent application process, allowing applicants to obtain a decision within 12 months. This was intended to reduce the (at the time) patent backlog, accelerating innovation. It also moved the U.S. patent system from a "first-to-invent" to a "first-inventor-to-file" system. This aligned the U.S. patenting system with those of other countries around the world.

In 2012, the Obama White House issued the National Bioeconomy Blueprint, [3] which laid out the Administration's strategic objectives for the bioeconomy. These included: strengthening relevant strategic $R \& D$, moving discoveries from the laboratory to the market faster, reducing regulatory barriers, developing a 21st century bioeconomy workforce, and promoting public-private partnerships. The Blueprint also emphasized the importance of biotechnology as a driver of the U.S. bioeconomic strategy. Since the Blueprint's release, federal agencies and other institutions initiated a suite of programs to promote the U.S. bioeconomy:

- The U.S. Department of Agriculture (USDA) expanded efforts to enable the procurement of bio-based products through the Biomass Crop Assistance Program [46], the BioRefinery Assistance Program (renamed the Biorefinery, Renewable Chemical, and Biobased Product Manufacturing Assistance Program) [47], and the BioPreferred Program [48].

- In 2016, the White House launched The Precision Medicine Initiative. Its aim was to use biological data and new analytics tools to derive inferences that could be applied to understand diseases and develop diagnostics and treatments for them [49].

- The U.S. Department of Energy (DOE) and USDA jointly released The Billion Ton Biomass report in 2016, which assessed the potential for producing and utilizing a billion tons of renewable biomass in the United States. The report identified the potential to annually produce 50 billion gallons of biofuels and 50 billion pounds of bio-based chemicals/product. This production could supply 25 percent of U.S. liquid transportation fuels, reduce $\mathrm{CO}_{2}$ emissions by 450 million tons and support 1.1 million direct U.S. jobs by $2030[50,51]$.

- In 2016, DOE established the Agile BioFoundry-the first open, public biofoundry-to address precompetitive research challenges identified by industry [52]. 
- In 2016, the National Science Foundation (NSF) launched its Big Idea initiative, including the Rules of Life Program [53].

- In 2017 the U.S Environmental Protection Agency (EPA) released its Update to the Coordinated Framework for the Regulation of Biotechnology, which was aimed at increasing transparency, streamlining regulatory processes while still ensuring safety, and accelerating the pace at which bio-inventions were brought to market [54].

- In 2017, USDA released an interagency task force report to the President. It outlined the importance of increasing public acceptance of biotechnology products, modernizing and streamlining the federal regulatory system for such products, and expediting their commercialization [55].

- In 2018, the biotechnology start-up LanzaTech partnered with Pacific Northwest National Laboratory and Virgin Atlantic airlines to develop and test new bio-based jet fuel [56].

- In 2019, the Biomass Research and Development Board of USDA and DOE issued The Bioeconomy Initiative: Implementation Framework [57].

- In 2019, the Engineering Biology Research Consortium (EBRC), a non-profit, publicprivate partnership, released Engineering Biology: A Research Roadmap for the Next-Generation Bioeconomy. The report outlined technical themes, applications, and key sectors for engineering biology [58].

- In 2019, the White House displayed renewed interest in the U.S. bioeconomy. In August, the Administration's FY2021 Research and Development Priorities budget memorandum identified the U.S. bioeconomy as a key area for federal R\&D investment [59]. In September 2019, the OSTP released a public Request for Information seeking input regarding what steps the federal government might take to promote and protect the U.S. bioeconomy [60]. In October 2019, it held a White House Summit on America's Bioeconomy to discuss U.S. bioeconomy leadership, challenges, and opportunities [61].

- In 2019, H.R. 4373 Engineering Biology Research and Development Act of 2019 was passed in the U.S. House of Representatives. The bill would direct OSTP to implement a National Engineering Biology Research and Development Initiative, designate an interagency committee to coordinate the initiative, establish an advisory committee on engineering biology R\&D; direct the NSF to partner with the NASEM to conduct a review and make recommendations regarding ethical, legal, environmental, and other societal issues related to engineering biology $R \& D$, and with other federal agencies including the National Aeronautics and Space Administration (NASA) to conduct research as part of the initiative [62].

- In May 2020, S.3734, the Bioeconomy Research and Development Act of 2020, which closely mirrors H.R. 4373, was introduced in the U.S. Senate [63].

In addition to the New Biology for the 21st Century report [44], other, recent NASEM reports have elaborated specific sectors of biotechnology. These include:

- Industrialization of Biology: A Roadmap to Accelerate the Advanced Manufacturing of Chemicals [64] addresses chemical and fuel production using microbial biotechnology, providing a roadmap for expanding applications of engineering biology to chemical production.

- Genetically Engineered Crops: Experiences and Prospects [65] examines the current evidence concerning both positive and negative effects of genetically engineered crops. It makes recommendations about improving safety assessments, improving regulations, furthering innovation, and increasing access to agricultural biotechnology.

- Preparing for the Future Products of Biotechnology [66] considers possible biotechnology developments over the next five to ten years and considers new regulatory frameworks needed to support these technologies.

- Biodefense in the Age of Synthetic Biology [67] considers how tools of synthetic biology could possibly be misused. 
- Gaseous Carbon Waste Streams [68] identifies feedstocks (e.g., carbon monoxide [CO], carbon dioxide $\left[\mathrm{CO}_{2}\right]$, methane $\left[\mathrm{CH}_{4}\right]$ ) that could potentially drive the U.S. bioeconomy.

Since 2013, NASEM has also worked with the science academies in the United Kingdom and China, conducting a series of symposia titled "Positioning Synthetic Biology to meet the Challenges of the 21st Century." NASEM also convened workshops in 2014, 2015, and 2016 to explore the bioeconomy, emerging technologies, and security concerns related to use of life sciences data.

The global bioeconomy, involves both economic rivalry and cooperation among nations. This cooperation includes significant scientific collaboration. The United States is not the only one recognizing economic advantages of investing in biotechnology R\&D or promoting one's bioeconomy. The European Commission, the Organization for Economic Co-operation and Development (OECD), and a number of individual European countries have developed their own position documents and bioeconomy roadmaps. In 2012, the United Kingdom launched its Synthetic Biology Leadership Council, co-chaired by representative from government and the private sector. China has identified the potential for synthetic biology to accelerate economic growth and has developed its own 20 year plans to carry this out.

\section{Defining the Bioeconomy: Alternative Approaches}

To develop a definition of the U.S. bioeconomy that accurately portrayed the breadth of scientific and economic activity (both current and potential) the NASEM Safeguarding report considered how other countries and academic entities have pursued their own definitions. Governmental bodies, academics, and business organizations throughout the world continue to develop new definitions of "the bioeconomy" to refer to a multitude of life sciences-related and biologically-based economic activities. There is currently no global consensus about how to define "the bioeconomy." Bugge et al. correctly note, "there seems to be little consensus concerning what a bioeconomy actually implies" [4], while Scordato et al. point that, as 2017, "it remains unclear what the bioeconomy is" [69]. The bioeconomy has been called "an emerging concept" [2], "a notion" [4], and a "policy concept" [5], while "the definitions have shown to evolve in a relatively short period of time" [19]. Different approaches to defining the bioeconomy have been characterized as different "visions" [4,69].

Previous studies have provided tables and lists of alternative definitions of the bioeconomy (e.g., $[4,15,17,33])$. A common element in these definitions is the use of biological resources. Definitions vary in terms of the emphasis they place on new uses of biological resources (e.g., new fuel sources, bioplastics, and other materials) or whether they consider traditional activities (e.g., agriculture, forestry, wood products, paper milling) part of the bioeconomy. They also vary in the explicit use of the term "biotechnology," although the term is usually included.

Many countries have developed separate strategies to promote their biotechnology industries and to promote bio-based products that substitute renewable biological resources for exhaustible fossil fuels. These distinct strategies have been, over time, combined in overarching definitions of the bioeconomy [17]. The value of simply listing bioeconomy definitions diminishes as the total number of definitions grows large, however. There has been a shift among scholars, from cataloguing bioeconomy definitions to studying the variation in definitions themselves to understand commonalties and divergences $[4,10,17,70]$. Bibliometric studies of bioeconomy publications have provided useful, detailed analyses that identify and quantify which fields of science, regions, and institutions are conducting research defining the bioeconomy [4-7,71].

Bugge et al. [4] distinguished between bioeconomy definitions in terms of three different "visions" of the economy. These three: a biotechnology, a bioresource, and a bioecology vision capture different aspects of the bioeconomy. This distinction in terms of visions has been maintained by other researchers $[70,72,73]$ and the NASEM Safeguarding report adopted this as well. 


\subsection{Biotechnology Vision}

Under the biotechnology vision, recent advances in biotechnology are core features of the bioeconomy. This is exemplified in the U.S. National Bioeconomy Blueprint [3,74]. In the Blueprint, released in 2012, the United States became the first country to emphasize biotechnology as a key driver of the bioeconomy. More countries are now featuring biotechnology as part of their overall bioeconomy strategies. Over the past year, Canada [75], Germany [76], Japan [77], and the United Kingdom [78] all released new "biotechnology" bioeconomy strategies. Today, biotechnology is seen to be a new area of economic and technological competition [3,13-16,79].

Defining the bioeconomy under the biotechnology vision follows an example-driven approach, which highlights specific products and production processes. Many of the first applications of novel technologies or new bio-based products have been in more traditional sectors, such as agriculture and forestry. This presents a challenge for technologybased definitions of the bioeconomy. It raises questions about whether to limit what to consider part of the bioeconomy to only newer applications, such as biofuels or genetically modified (GM) crop varieties, or to consider all crop and forest production as part of the bioeconomy. For example, studies of China [13,80], other Asian countries [80], the United States [74], Latin America [20], and OECD countries [81], in addition to the U.S. Blueprint [3], all consider the diffusion of GM crop varieties as a key performance indicator for the bioeconomy. In contrast, EU countries tend to consider all crops as part of the bioeconomy, with no special reference to GM crop diffusion. The EU de-emphasis of GM crops reflects a more hesitant approach to deployment of agricultural biotechnology, with commercial cultivation of GM crops currently banned in a number of individual EU countries [82].

Countries have adopted different approaches toward treatment of medical applications in their definitions of their bioeconomies. Most definitions adopted by countries now consider bio-based pharmaceuticals to be part of the bioeconomy. The United States and China, though, have included a broader set of medical applications. For China, Li et al. considered vaccines (both animal and human), gene therapies, genome sequencing, tissue-engineering products, and immunological diagnosis [13]. These technologies and applications are similar to those emphasized in the U.S. Blueprint [3]. Nordic countries have emphasized functional foods and nutraceuticals designed to promote health [83]. The current SARS-CoV-2 coronavirus pandemic has focused efforts on rebooting economies with bioeconomy strategies, highlighting the risks associated with reliance on global supply chains for preparedness and response, and has caused countries to re-examine exclusion of health fields from their bioeconomy strategies. Countries also vary in how much emphasis they place on measuring biotechnology-related R\&D, with the United States, Canada, and China giving it greater emphasis $[3,13,74,79]$. Generally, European countries have deemphasized biotechnology R\&D, with Germany [84] and Sweden [85] being notable exceptions. Some studies have also included applications of bioleaching applications in mining as part of the bioeconomy [13,86-88].

\subsection{Bioresource Vision}

The bioresource vision of the bioeconomy focuses on substituting renewable biological resources for fossil fuels as the basis for transportation fuels, electricity production, and chemical manufacturing. A key goal is to develop new value chains in traditional, biologically-based industries [4]. Countries consistently include such activities in their definitions of and strategies for the bioeconomy. Countries, however, place differing emphasis on different goals as rationales for bioresource substitution. These can include rural development, energy security and self-sufficiency, climate change mitigation, and attaining sustainable development goals (SDGs) $[4,8,10,73,83]$.

U.S. federal agencies, to date, have not developed a consistent set of economic activities, products, or technologies to include in their definitions of bio-based production. The 2015 USDA BioPreferred report to Congress [89], and 2018 report update [90] evaluates 
seven bio-based product industries contributing to the U.S. economy. These included agriculture and forestry, forest products, natural-fiber (e.g., cotton) textiles, biorefining, bio-based chemicals, enzymes, and bioplastic bottles and packaging. It excluded pharmaceuticals and agriculture for food, feed, or biofuels production. Under this scheme, 92 percent of the economic contribution to value-added came from mature, traditional economic sectors. Logging, timber, and wood products accounted for 81 percent of bio-based value-added, while cotton production and cotton-based textiles and apparel contributed another 11 percent. Value-added summed over all industries nationally equals a country's gross domestic product [GDP]). New forms bio-based manufactured products accounted for only 8 percent of direct value-added from bio-based production. In contrast to the BioPreferred reports, the DOE's Billion-Ton report [50] focused on bioresource supply potential. It considered a broader set of products and technologies and products, which included anaerobic digestion, bio-based chemicals, biodiesel, ethanol, landfill gas, woody biomass, and wood waste.

\subsection{Bioecology Vision}

The bioecology vision of the bioeconomy emphasizes "the importance of ecological processes that optimize the use of energy and nutrients, promote biodiversity, and avoid monocultures and soil degradation" [4]. The bioecology vision, similarly to the concept of the circular economy, also emphasizes the recycling and reuse of resources. In the $\mathrm{EU}$, economic policies have increasingly adopted a circular economy approach, where resource waste is minimized, while moving away from a "linear economy approach" that emphasizes "taking," "making," and "disposing." A circular economy, in contrast emphasizes product longevity, reuse, repair, and recycling of materials. Scholars have argued that the bioeconomy and the circular economy represent distinct, but complementary concepts $[2,91]$. While the bioeconomy places greater emphasis on the role of biological science and processes, certain bio-based energy production and consumption are external to the circular economy $[2,91]$.

In the EU, the concept of the "circular bioeconomy" has gained traction. Policies are being developed to increase the use of bio-based resources regarded as wastes (e.g., agriculture and forestry residues). Here, the long-term objective is to substitute bio-based production for production based on fossil fuels [91-93].

Biodiversity, commonly understood as the variety of living organisms within their natural environments, is critical to the bioeconomy for a number of reasons. First, maintaining the richness of biodiversity is essential for sustaining life on earth. Second, genetic resources have long been a source of technological advance and product development in agriculture and medicine. Half the yield gains since the 1930s of major field crops in the United States have been attributed to genetic improvements in crop varieties, often though crossbreeding [94]. Soejarto and Farnsworth [95] have estimated that roughly a quarter of prescription drugs contain some natural products. This percentage increases further if one considers that traditional medicines used in developing countries rely on natural products [22]. The molecular structures of natural products can also serve as blueprints for-or as research leads in - the development of new compounds [28,96]. In addition to pharmaceuticals, natural products have provided an array of chemical structures that have served as starting points in the development of many insecticides, herbicides, and fungicides [97]. Third, the capacity to manipulate biodiversity through the use of metabolic engineering and synthetic biology is fueling parts of a purposeful bioeconomy. This could be thought of as creating a new "synthetic" or "digital" realm of biodiversity, manifested as biological tools and new marketable products.

Biodiversity is a rich, natural and renewable resource that feeds into myriad components of the bioeconomy. Conversely, biodiversity loss represent potential costs in the form of missed or unrealized opportunities for the bioeconomy. Most U.S. agricultural crops are monocultures. Relying on single varieties of crops increases agriculture's vulnerability to pests and pathogens. It can also diminish ecosystem services inherent in more diverse 
landscapes. Proponents of the bioecological vision of the bioeconomy often stress the need for diversity in multiple dimensions. This includes the types of crops grown, how they are grown, and their genetic makeup [4].

Biodiversity traditionally has been leveraged for benefits in different ways across multiple sectors. Selection of desired agricultural traits depends on accessing broad genetic diversity within a species. This diversity is important for marker-assisted breeding programs, where genetic sequences guide the selection of traits. Synthetic biology and biotechnology tools have also been recently applied to convert biodiversity within and across species (transgenics), with demonstrable economic benefits. Genomic sequencing of a diversity of living organisms allows scientists to identify genes that could be utilized to create genetic pathways and circuits, using metabolic engineering to create high-value compounds. Much of the potential of biodiversity remains undiscovered. Yet industry exploration, such as R\&D of natural-product pharmaceuticals, has shown promise in the past and has received renewed interest $[98,99]$. For example, over the next decade, the Earth BioGenome Project plans to sequence, catalog, and characterize the genomes of earth's eukaryotic biodiversity [100].

\subsection{Reconciling Visions of the Bioeconomy}

The three different visions of the bioeconomy - the biotechnology, the bioresource, and the bioecology visions-are not necessarily mutually exclusive. Virtually all national bioeconomy strategies of different countries emphasize substituting away from fossil fuel-based production toward bio-based products. This is the fundamental aspect of the bioresource vision. Other countries, such as the United States, Canada, China, several Latin American countries, Germany, the United Kingdom, and Malaysia also simultaneously emphasize biotechnology in defining their bioeconomies [13,20,74,101]. There are cases of conflict between bioeconomy visions, however. For example, some definitions following the bioecology vision explicitly reject inclusion of genetically modified crops as part of the bioeconomy [4]. In other cases, though, one can find aspects of all three visions in a country's bioeconomy strategies. For example, the U.S. National Bioeconomy Blueprint emphasizes biotechnology and health applications, in keeping with the biotechnology vision [3]. The Department of Energy's Billion-Ton report [50] and the 2015 USDA BioPreferred report to Congress [89] emphasizes substituting renewable biological resources for fossil fuels, in keeping with the bioresource vision. Third, in keeping with the bioecology vision, the Earth BioGenome Project [100] addresses risks to biodiversity from climate change.

\section{Defining the U.S. Bioeconomy}

Definitions of the "the bioeconomy" vary by country and context. The NASEM Safeguarding report identified four drivers of the bioeconomy in the U.S. context (Figure 2). Life sciences are the first driver, which includes biology and its sub-disciplines that provide an understanding of life on earth in its many forms. Sub-disciplines include botany and agronomy, which focus on plants and agriculture, microbiology, which focuses on singlecell organisms, and environmental biology, which studies how plants and animals interact with their environment.

Biotechnology is the second driver. It enables an understanding of biology at the level of DNA, the code for all living organisms. Biotechnology advances have made it possible to, not only read genetic code but to write it, and to engineer it to cure a disease, improve crop yields, address an environmental problem, and produce bespoke bio-products. Advances in biotechnology have enabled new methods to grow and analyze cells and tissues and to purify enzymes to be used to drive chemical reactions outside of their native cellular context. Examples include: analytical chemistry, next-generation sequencing, epigenetics, and gene and genome editing. All of these powerful biotechnology tools have accelerated the development of applications for the bioeconomy. 


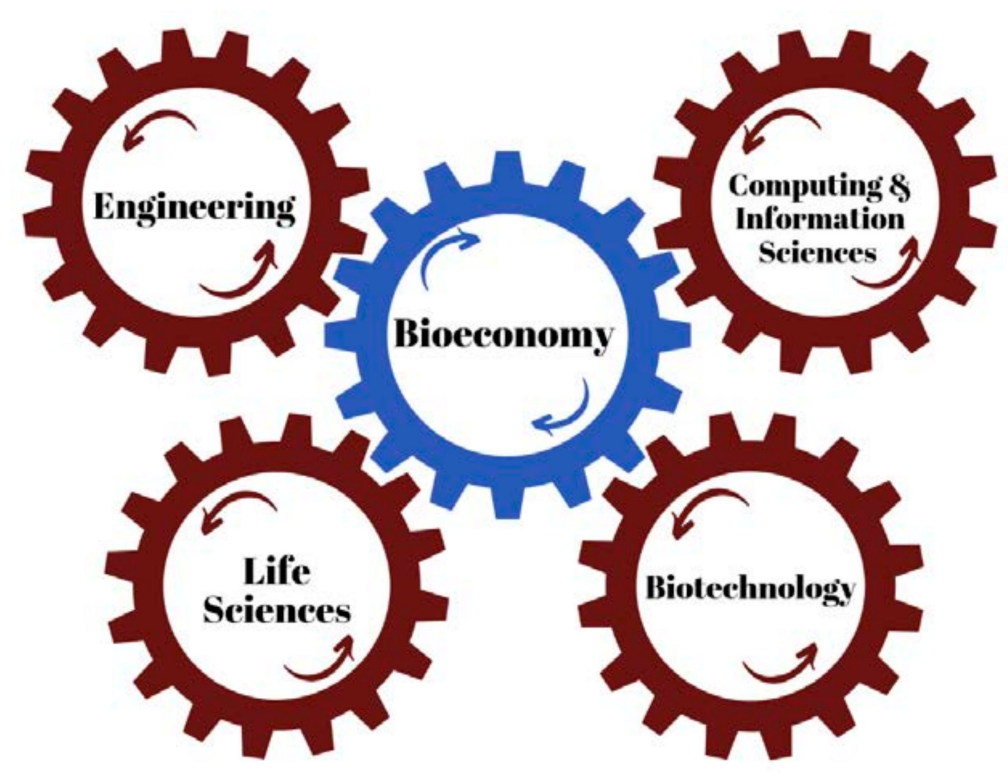

Figure 2. Four Drivers of the U.S. Bioeconomy from the National Academies of Science, Engineering, and Medicine (NASEM) Safeguarding report [1].

Advances in biotechnology require experimentation. Whether it is a biotechnology drug, a genetically modified crop, or a new detergent enzyme, bringing an innovative product to market requires literally millions of experiments. Now, though, it is possible via engineering to automate and miniaturize the experimental process. Advances in microfluidics and robotics support high-throughput techniques for product development, while advances in analytical techniques allow results to be derived, using smaller samples. In addition to microfluidics and robotics, tissue engineering, cell culture, and advanced fermentation are examples of the use of engineering to develop and manufacture bioeconomy products. Furthermore, the application of engineering principles to biology (design-build-test, for example) has accelerated advances in synthetic biology.

To accomplish this, computing and information sciences make it possible to model experiments mathematically before running them and to develop predicted outcomes. Advanced computing techniques, such as machine learning, have enhanced our capacity to observe nonobvious patterns in large, complex datasets. This allows researchers to make "wise guesses," eliminate improbable experiments, and focus on pursuing the most promising leads. Biological datasets, from genomics, proteomics, metabolomics, and the other "omics" can be paired with imaging data, medical clinical observations, plantbreeding records, workplace exposure data, family histories, and lifestyle information from social media. Applying artificial intelligence tools to these datasets will increase our understanding of linkages between cause and effect and between genotype and phenotype. It is this deeper understanding of these linkages that holds particular promise for the future of the U.S. bioeconomy.

Keeping the history of the U.S. Bioeconomy and these factors in mind, the NASEM Safeguarding report [1] recommended the definition:

"The U.S. bioeconomy is economic activity that is driven by research and innovation in the life sciences and biotechnology, and that is enabled by technological advances in engineering and in computing and information sciences."

This definition encompasses economic activity relating to all products, processes, and services that interact with or are built specifically for "research and innovation in the life sciences and biotechnology." The intent is for this definition to be sufficiently flexible to anticipate, to account for, and to include advances and new applications in the life sciences and biotechnology. These include innovations such as the use of CRISPR (clustered regularly interspaced short palindromic repeats) technology for genome editing or applications 
of cellular agriculture. In addition, this definition references the contributions that other disciplines have made to the life sciences. For example, engineering has enabled highthroughput experimentation, while computing and information sciences have facilitated the collection, analysis, sharing, and storage of biological information. Such enabling technologies have transformed life science research, opening up new avenues for R\&D.

\section{Approaches to Defining Bioeconomy Landscapes}

Beyond the initial step of developing a working definition of the bioeconomy, are the goals of measuring the economic scope and contribution of the bioeconomy to the overall economy and developing performance metrics to evaluate the success of strategies to promote the bioeconomy. The movement from definition to measurement naturally leads to what the NASEM Safeguarding report refers to as defining the landscape of the bioeconomy-deciding which economic sectors and sub-sectors to include as a direct component of the bioeconomy and which to consider external to it. This classification is an intermediate step in measuring the contribution of the bioeconomy to the total economy of region or country. Chapters 3 and 4 of the Safeguarding report discuss methodological issues surrounding measurement of the bioeconomy's economic contribution. Evaluation of the full economic contribution of the bioeconomy acknowledges and accounts for the fact that economic activity within the bioeconomy stimulates demand, sales, and employment in other parts of the economy via economic multiplier effects.

The bioeconomy is not comprised of a set of discrete economic sectors. Rather, it spans multiple sectors. Because of this, developing a bioeconomy landscape definition is challenging. Previous efforts, however, have followed a common overall approach, at least as a starting point. First, certain sectors are considered wholly within (e.g., biotechnology R\&D) or outside of (e.g., steel manufacturing) the bioeconomy. What remains is a set of "mixed" [102] "partly included" [103], or "hybrid" [104] sectors. For example, bioplastics (part of a larger plastics manufacturing industry) or soy printer ink manufacturing (part of the larger printing ink manufacturing industry) would be part of the bioeconomy. So, for some sectors, a subset of economic activities would be within the bioeconomy; the remainder, not.

North American studies [87,90,105-108] have taken a distinctly different approach to defining their bioeconomy landscapes than European countries [102-104,109-114] and Japan [115]. EU studies tend to use a relatively broad definition of the bioeconomy landscape and include, in their entirety, economic sectors that produce or fundamentally rely on biologically produced materials. For example, primary sectors (other than mining) such as agriculture, forestry and fisheries are included. Food, beverage, tobacco, and wood products manufacturing are also included. EU ministries have identified research and innovation as a key bioeconomy indicator. Yet, EU countries often exclude biotechnology R\&D the bioeconomy landscapes [84]. In the United States and Canada, there has been greater emphasis on applications of biotechnology, and biological R\&D. The substitution of bio-based products for fossil fuel-based ones in manufacturing within traditional sectors has also been emphasized. Here, crop production, livestock production, forestry, and fisheries are largely excluded from the bioeconomy. Two important exceptions are crops grown for energy production and genetically modified crops, which are included in the bioeconomy landscape [74].

Lier et al. surveyed ministries from EU member states that have been tasked with monitoring the performance of their bioeconomies or with developing bioeconomy strategies [103]. Respondents were asked which economic activities were completely included, partly included, or not included in their bioeconomies. Combining country responses, Lier et al. identified 15 different sectors as part of the bioeconomy. Not all countries included the same sectors, however. Only three of the 15 industries were listed as completely included in the bioeconomy by all respondents: agriculture, forestry, and the food industry. Countries differed on their level of inclusion, with respect to the other twelve. Most countries included aquaculture, fisheries, wood products manufacturing, and pulp and paper 
manufacturing as wholly within in their bioeconomies. Some ministries also included hunting, nature-based tourism and recreation, transportation of bio-based products, and even some construction activities as either wholly or partly in their bioeconomies. For these latter activities, there was much less agreement.

Most ministries in EU countries identified "investment in research and innovation" as a key indicator of performance for their bioeconomy [103]. Yet, in general, they have not included biotechnology R\&D or more general life science R\&D as part of their bioeconomies. This is despite the fact that the EU's Nomenclature générale des Activités économiques dans les Communautés Européennes codes, which classify economic activities in the European Community, have a distinct code, 72.11 Research and experimental development on biotechnology, which would facilitate the inclusion and measurement of biotechnology R\&D. In contrast, Sweden does include activities within code 72.11 as part of their bioeconomy [85]. Similarly, analysis of the Central Germany found that 18 percent of firms within the bioeconomy were categorized under scientific R\&D industry codes [84].

There are trade-offs involved in adopting narrower versus broader definitions of which economic activities one includes in the bioeconomy. If one adopts a broad, highly inclusive definition of the bioeconomy, this has the advantage of including several sectors, such as agriculture, forestry, wood manufacturing, and food processing, in their totality. These sectors are already well-defined and measured in consistent ways across countries in their national income accounts and other government economic statistics. This facilitates measurement across countries and regions and over time. Yet, a distinct disadvantage of such broad measurement is the fact that the bioeconomy is then dominated (in terms of output, employment, etc.) by "mature" economic activities, such as wood furniture manufacturing that do not rely on applications of biological research or biotechnology or (to date) involve much substitution of biological for petrochemical resources. Primary production, food processing, and manufacturing of wood and paper products are also economic sectors where economic activity (e.g., sales, value added, employment, total wage payments) has been shrinking as a share of the overall economy. Thus, weighting the bioeconomy toward these sectors could likely portray that, relative to the overall economy, a country's bioeconomy is shrinking in size and economic consequence over time.

By adopting a narrower definition of the bioeconomy landscape, one based on the penetration of biological innovations, one may be better equipped to track innovation and dynamism within mature sectors of the economy. For example, under a narrower definition of the bioeconomy landscape, the entire forestry sector, may not be included. If, however, future biotechnology applications in the forestry sector progressed, those activities would be included in the bioeconomy, while the diffusion of those applications would be measured as growth in the bioeconomy. Crop agriculture is another example. Under a narrower definition, all crops would not automatically be included, but genetically modified crops or crops used for biofuel or bioelectricity production would be. Again, tracking diffusion of these technologies would capture growth in the bioeconomy, even when the relative size of total crop production was shrinking in relative terms in the overall economy. Similarly, innovations in cellular agriculture could bring more livestock production or food processing activities under the umbrella of the bioeconomy.

Yet, there are disadvantages to adopting too narrow of definition of what is within the bioeconomy as well. If criteria about what to include in the bioeconomy is based on the novelty of technologies, applications or uses, then what activities or sub-sectors are included in the bioeconomy will need to be revised frequently. This will make it more difficulty to collect data, measure activity or track the performance of the bioeconomy over time and across countries. There is a possibility that the generation of official statistics will always be "one step behind." For example, advances in biological innovations and biological applications of informatics are leading to rapid technological change in agriculture. Keeping pace with the diffusion of these innovations and how they affect economic activity will require continual adjustment costs. 


\subsection{Defining the U.S. Bioeconomy Landscape}

Figure 3 highlights the sectors and activities the NASEM Safeguarding report considered within the U.S. bioeconomy landscape. The report's definition emphasized the role of biotechnology and this is reflected in the landscape illustrated in the figure. In addition, crop, livestock, forest products, and textiles sectors have potential applications, currently in the R\&D phase, which may be commercialized in the near future. With the diffusion of these new technologies, it will be necessary to regularly reassess whether new goods and services produced or supplied in novel ways belong in the bioeconomy. For example, the forestry sector, in its totality was not included in the U.S. bioeconomy. This was because biotechnology applications or forest biomass for fermentation have not (to date) been significant. This could soon change, however. There are potential future applications of biotechnology to promote and protect forest health [116]. As these applications diffuse, forestry could become an important contributor to the bioeconomy.

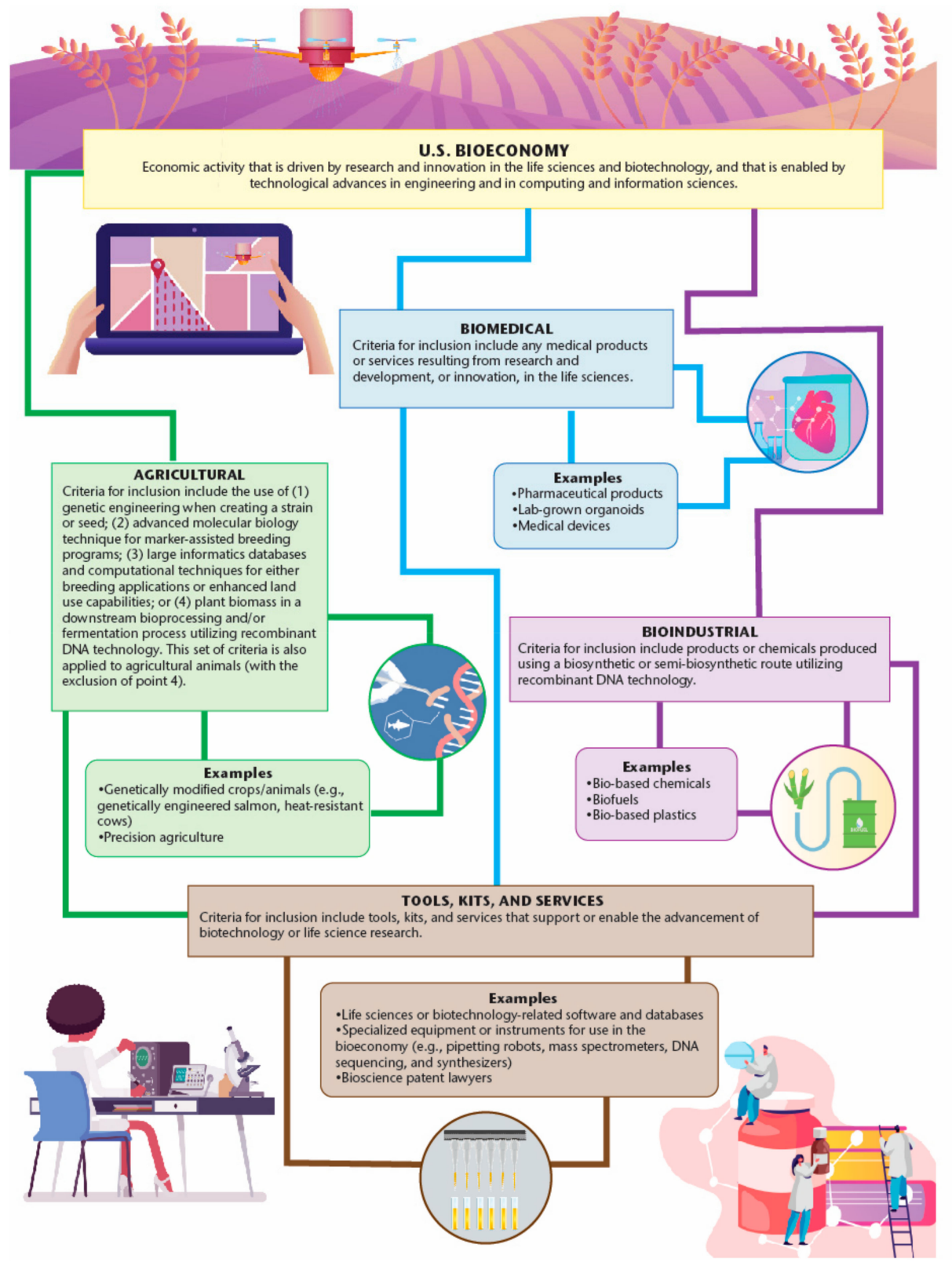

Figure 3. The bioeconomy landscape: examples falling under the bioeconomy definition from the Safeguarding the Bioeconomy [1] Report. 
The Engineering Biology Research Consortium's Engineering Biology [58] and the NASEM's Preparing for Future Products of Biotechnology [66] outline a number of new and exciting products and biotechnologies that would be included in the above bioeconomy landscape. Platform technologies to create engineered strains of microorganisms that perform specific biosynthetic functions are examples of biotechnology products and firms that fall within the bioeconomy $[117,118]$. Others are microorganisms developed to clean up the environment by recycling metal or acting as environmental biosensors, clothing made from biosynthetic spider silk [117], and meat substitutes made with biosynthetic protein additives from yeast, such as the hemoglobin used to give the product a "meaty" flavor [119]. To explain how the NASEM Safeguarding bioeconomy definition informs the bioeconomy landscape, we next present some concrete examples along with the report's rationale for including them.

\subsubsection{Agriculture}

According to the Safeguarding definition, the U.S. bioeconomy includes most crop production. This is because many crops grown in the United States interact with biotechnology or research in the life sciences during their life cycle. There are four main criteria for inclusion within the agriculture sector that allow consistency with the definition. The first is the use of genetic engineering when creating a strain or seed. The second is using advanced molecular biology techniques for marker-assisted breeding programs. The third is using large informatics databases and computational techniques for either breeding applications or enhanced land-use capabilities (i.e., precision agriculture). The computational approaches in this criteria include breeding capabilities such as accelerated breeding techniques and examination of genomes to plan genetic crosses. Additionally, computational techniques can enhance land use when drone or artificial intelligence technologies are used to help with everything from water management to weed and pest scouting. The final criterion is using plant biomass in a downstream bioprocessing and/or fermentation process utilizing recombinant and synthetic DNA technologies. These criteria would exclude any crop varieties that do not meet these four criteria from the assessment of the U.S. bioeconomy.

The first three criteria also apply to animal products. In 2019, the United States gave approval to the biotech company AquaBounty to grow and sell GM salmon in the United States [120]. AquaBounty salmon had earlier been approved and are already sold in Canada. Food products from genetically engineered land animals have yet be approved and commercialized in the United States. This may soon change. Researchers have engineered cattle that are heat-resistant to help them survive in warmer climates [121], as well as cattle that are "polled" (meaning without horns), making it safer for both their human handlers and the cattle themselves, because dehorning cattle is painful and dangerous [122]. Insects are being developed as both a food source and a means of pest control. One company is using farmed insects for protein in products such as pet food [123], while a genetically engineered moth is being used for pest control in the production of cabbages [124]. These products would be included in the bioeconomy, and will start to make larger economic contributions as they clear regulatory hurdles.

Additional examples of animal products included in the bioeconomy include "labgrown meats," also referred to as "cellular agriculture." While not the same as a classic "meat alternative," "lab-grown" meat is "the use of animal cell culture technology to grow animal tissue directly from animal cells, rather than from a live animal" [125]. In this process, muscle cells are cultured from biopsies to produce the exact composition of animal meat without the need for animal husbandry. This is another example of a meat product relying heavily on new biotechnologies and would so be included in the bioeconomy.

\subsubsection{Biomedical Applications}

The Safeguarding definition would include in the bioeconomy any medical products or services resulting from life sciences $R \& D$. All pharmaceuticals require significant research 
and safety testing before they can be approved and allowed onto the market. The research needed to produce a final pharmaceutical product frequently includes the drug discovery paradigm of using biological information and processes to obtain an initial product. That initial product is iteratively tested and screened for safety and efficacy before it is produced at scale. Engineering processes are used increasingly to identify a starting drug molecule. Such processes include automated screening of large chemical libraries to identify a starting drug molecule and in silico screening of molecules in the binding regions of important protein targets. These steps all require "research and innovation in the life sciences," as the Safeguarding definition denotes. This means that all pharmaceutical products, and the processes needed for their discovery, are part of the bioeconomy.

Biological R\&D is also critically important for developing medical devices. Some devices require extensive use of newly developed biotechnologies and the latest biological research. One example is the brain-controlled robotic arm, including a new version using noninvasive brain-computer interface, avoiding the need for invasive surgery [126]. Other devices being developed rely heavily on advances in human biology. These include cell-based biosensors for diagnosis and lab-grown organoids. All medical devices are considered within the bioeconomy because their development all require life science R\&D.

\subsubsection{Bioindustrial Applications}

As with the downstream fermentation processes in agriculture, any product or chemical produced using a biosynthetic or semi-biosynthetic route utilizing recombinant DNA technology is included in the bioeconomy. However, chemicals manufactured through strictly chemical synthesis are excluded. The common industrial additive 1, 3-propanediol (PDO) provides an example highlighting the biosynthetic versus chemically synthetic processes for producing a chemical. This product can be produced at large scale using genetically modified bacteria to convert a sugar-based starting product into the desired chemical [127]. Applications include adding durability to carpets and rugs [128]. Here, a chemical previously produced through chemical synthesis, is now produced primarily through a biosynthetic process. There are inherent challenges to measuring the contribution of production of certain chemicals to the bioeconomy. At present, there are not adequate data to determine what fraction of the total production of manufactured chemicals are made via fermentation versus chemical synthesis.

\subsubsection{Cross-Cutting Tools, Kits, and Services}

Tools, kits, or services supporting or enabling the advancement of biotechnology or life sciences research would be included in the U.S. bioeconomy landscape. This recognizes that it can be difficult to decouple tools or services that function both within and outside the defined parameters of the bioeconomy. A clear example of a supporting tool is a software used specifically in life sciences laboratories. Software such as SnapGene, used to view and analyze genetic sequences, would be included because it is a computing technology that functions primarily to advance research in the life sciences. Standard word processing software, however, would be excluded because of its many other applications. As technologies for acquiring data have advanced, there has been significant growth of life science-specific databases, such as those of genomic sequences that are part of the bioeconomy. These include data collected from medical and laboratory specimens, in addition to data produced from consumer-based genomic testing, such as $23 \mathrm{andMe}$ and Ancestry ${ }^{\circledR}$.

Life sciences-specific instruments, such as pipetting robots, are part of the bioeconomy. DNA sequencing and synthesis technologies are also important across all bioeconomy sectors. Many of the products and services described in this landscape rely on the ability to sequence and synthesize DNA with increasing speed and falling costs (see Chapter 5 of $[1,66]$. Mass spectrometers and other instruments are critical to the bioeconomy, yet also serve scientific functions completely outside the bioeconomy. Mass spectrometers are the workhorse instruments in the fields of proteomics and metabolomics, important 
analytical fields of life science. However, mass spectrometers are also critical to the field of chemistry, helping, for example, with analyzing and identifying small-molecule products. These different applications make it difficult to parse out the economic contributions of mass spectrometers to the bioeconomy.

In addition to tools and instruments, services that advance biotechnology and the life sciences are included in the bioeconomy. This would, for example, include services of bioscience patent lawyers who help move new biotechnologies through the complex system of patent laws [108]. Bioscience patent lawyers have expertise specific to the bioeconomy, understanding both biotechnologies they are guiding through the patent process in addition to expertise in patent law. The specificity of their expertise differentiates these legal services from more general legal services that, while important to biotechnology and the life sciences, do not require biotechnology-specific knowledge or training.

\subsubsection{Intangible Assets}

Life science-specific datasets, such as databases of genomic sequences, are valuable parts of the bioeconomy. As are patents and proprietary technologies, these datasets are intangible assets that can pose challenges to valuation of the bioeconomy. The Safeguarding report outlined a framework suitable for valuing intangible assets common to companies in the U.S. economy (such as intellectual property, brand equity, software programs). This also included data and other intangible assets held by the public sector. This includes, for example, the GenBank sequence database, an open-access, annotated collection of all publicly available nucleotide sequences and their protein translations. The National Center for Biotechnology Information (NCBI), a division of the National Library of Medicine, maintains this database and software used to access it. Genbank datasets have grown quickly since its inception in 1992. This suggests that public data have significant value for biomedical and bioindustrial analysis. If biological data assets are important inputs to scientific and commercial advances, the beneficial impacts of open biological data will spill over to productivity in the business economy (via new industrial and consumer biotechnology products) and generate benefits to human health via improved treatments for diseases. While the economic value of NCBI has not been specifically investigated, economists have documented the importance of public databases for the progress of knowledge in science and innovation. For example, Furman and Stern have demonstrated that public libraries for biological materials enhance the rate of knowledge generation associated with deposited materials [129]. There is a vast set of data assets, from precision agriculture data to human and bacterial genome data and more, contributing to the U.S. bioeconomy.

\section{Defining the U.S. Bioeconomy Landscape: Moving Forward}

It can be difficult to measure the economic activity related to the bioeconomy for products or services that have multiple applications. Computer software has been mentioned already. Further, economic sectors measured and reported at high levels of aggregation in U.S. national income accounts would be treated as mixed or hybrid sectors. While some activities would be within the bioeconomy, others would be outside of it. Larger sectors with elements of the bioeconomy within them as sub-sectors would include agriculture (e.g., genetically modified crops); utilities (e.g., biomass electricity); food and beverage and tobacco products (e.g., bioengineered products); chemical products (e.g., pharmaceuticals, bio-based chemical products); plastics and rubber products (e.g., bioplastics); professional, scientific, and technical services (biotechnology R\&D); and ambulatory health care services (e.g., certain medical laboratory services).

At finer scales of sector definition than those used to report GDP, industries are classified in the United States, Canada, and Mexico in terms of North American Industry Classification System (NAICS) codes and according to Nomenclature générale des Activités économiques dans les Communautés Européennes (NACE) codes in the EU. These more disaggregated classification systems are extremely useful for parsing out which activities are wholly included, wholly excluded, or partially included. For example, biomass electric 
power generation (NAICS 221117) or R\&D in biotechnology (NAICS 541714)) would be considered within the bioeconomy, while printing ink manufacturing (NAICS 325910) would be a mixed sector. Soy ink production would be included in the bioeconomy, while non-biobased ink production would not.

The soy ink example illustrates that, even at relatively fine sector definitions, many sectors reported in standard statistics of the U.S. economy will be mixed (i.e., with only a subset of activities considered part of the bioeconomy). To address this problem, some studies have conducted industry surveys to assess which types of production within a sector are "bio-based" (e.g., [89,102,130]. Plastics manufacturers, for example, might be surveyed to estimate what share of their production and employment is devoted to bioplastics. This subset of their production, bioplastic production, would then be included in the bioeconomy. Another possible approach would be revise the NAICS codes to better capture bioeconomy activity $[74,108]$. Chapter 3 of the NASEM Safeguarding report discusses possible useful changes to NAICS code definitions that would facilitate more accurate measurement of the bioeconomy [1].

Chapter 3 of the Safeguarding report also examines methods and data to estimate the contribution of the bioeconomy to the overall U.S. economy. The direct contribution to value added (GDP) was estimated (based on 2016 data) to be USD 402.5 billion. Including indirect and induced multiplier effects, the total contribution of the bioeconomy to U.S. GDP was estimated to be nearly a trillion dollars (USD 952.2 billion) [1].

The bioeconomy landscape defined in the Safeguarding report takes as a starting point, a narrower set of economic activities compared, for example, to approaches undertaken in the EU. Yet, the Safeguarding report approach recognizes that defining the bioeconomy will continue to be a dynamic process. While EU studies have adopted broader definitions of the bioeconomy landscape, there will likely be a convergence in what is assessed and measured. For example, the EU's BioMonitor Project recognizes the bioeconomy can be divided into traditional activities (e.g., agriculture, food processing, paper, etc.) and "emerging activities" (within chemical and pharmaceutical sectors) [131]. The Project recognizes that the traditional sectors are already comprehensively covered in traditional national accounts, while the emerging activities will require special focus and data gathering to capture technological dynamism and growth in bio-based production non-traditional sectors.

As economies around the world struggle with the consequences of the SARS-CoV-2 coronavirus pandemic, emerging bioeconomy ecosystems serve as experimental testbeds for possible solutions. A 2019 analysis of bioeconomy ecosystems by the OECD examined the policy aspects of building the industrial and innovation ecosystems and value chains needed to make bioeconomies viable as a sustainable means of production. Among the global case studies examined, the OECD concluded that for the U.S., a number of key points are relevant: the bioeconomy creates jobs and wealth, whole-of-government action and coordination across relevant agencies is critical, public-private partnerships are powerful and should serve a broad array of stakeholders, and engineering biology and computing are drivers of innovation ecosystem hubs [132]. New legislation moving through Congress may capitalize on these assets and result in a new strategic bioeconomy initiative similar to the 21st Century Nanotechnology Research and Development Act, which catalyzed the U.S. nanotechnology industry [133].

\section{Summary and Conclusions}

This article has provided a history of efforts to conceptualize and define the U.S. bioeconomy. It also identified seminal research publications, government reports, and policy initiatives over the last 25 years to understand and promote the bioeconomy. This historical overview culminated with in-depth discussion of the definition of the U.S. bioeconomy recommended in the National Academies of Science, Engineering, and Medicine (NASEM) report, Safeguarding the Bioeconomy [1]. This discussion has highlighted the variety of approaches taken by scholars and governments in defining their bioeconomies. Earlier North American approaches tended to begin from a narrower approach while others (e.g., 
in the EU) have tended to take a broader approach. The NASEM Safeguarding report and recent activities in the EU (e.g., the BioMonitor Project) suggest some movement toward convergence of approaches, which will hopefully facilitate future research collaboration and policy cooperation.

Author Contributions: All authors contributed to the original NASEM Safeguarding report, serving as a basis for this article. G.B.F. was responsible for the initial organization and review of literature on the history and comparative definitions of the bioeconomy, as well as analysis of how definitions were used for sectoral measurements of the bioeconomy. M.E.M. was responsible for discussion of U.S. and international bioeconomy strategies leading up to and subsequent to the NASEM report in addition to description of biological and chemical processes and innovations. S.M.M. and A.H. were responsible for discussion or the history and motivation of the NASEM report, integrating sections, and discussion new innovations in the U.S. All authors have read and agreed to the published version of the manuscript.

Funding: This research received no external funding.

Institutional Review Board Statement: Not Applicable.

Informed Consent Statement: Not Applicable.

Data Availability Statement: Not Applicable.

Conflicts of Interest: The authors declare no conflict of interest. The views expressed are those of the authors and not necessarily those of the National Academies of Science, Engineering, and Medicine.

\section{References}

1. NASEM (National Academies of Sciences, Engineering, and Medicine). Safeguarding the Bioeconomy; The National Academies Press: Washington, DC, USA, 2020.

2. Wesseler, J.; von Braun, J. Measuring the bioeconomy: Economics and policies. Ann. Rev. Resour. Econ. 2017, 9, 275-298. [CrossRef]

3. White House. National Bioeconomy Blueprint; White House: Washington, DC, USA, 2012; p. 48. Available online: https:// obamawhitehouse.archives.gov/sites/default/files/microsites/ostp/national_bioeconomy_blueprint_april_2012.pdf (accessed on 25 April 2020).

4. Bugge, M.; Hansen, T.; Klitkou, A. What is the bioeconomy? A review of the literature. Sustainability 2016, 8, 691. [CrossRef]

5. Birner, R. Bioeconomy concepts. In Bioeconomy: Shaping the Transition to a Sustainable, Biobased Economy; Lewandowski, I., Ed.; Springer: Cham, Switzerland, 2018; pp. 17-38.

6. Golembiewski, B.; Sick, N.; Bröring, S. The emerging research landscape on bioeconomy: What has been done so far and what is essential from a technology and innovation management perspective? Innov. Food Sci. Emerg. Tech. 2015, 29, 308-317. [CrossRef]

7. Nobre, G.C.; Tavares, E. Scientific literature analysis on big data and Internet of things applications on circular economy: A bibliometric study. Scientometrics 2017, 111, 463-492. [CrossRef]

8. Dietz, T.; Börner, J.; Förster, J.; von Braun, J. Governance of the bioeconomy: A global comparative study of national bioeconomy strategies. Sustainability 2018, 10, 3190. [CrossRef]

9. Teitelbaum, L.; Boldt, C.; Patermann, C. Global Bioeconomy Policy Report (IV): A Decade of Bioeconomy Policy Development Around the World. A report to the International Advisory Council on Global Bioeconomy; Secretariat of the Global Bioeconomy Summit: Berlin, Germany, 2020.

10. Bracco, S.; Calicioglu, O.; Gomez San Juan, M.; Flammini, A. Assessing the contribution of bioeconomy to the total economy: A review of national frameworks. Sustainability 2018, 10, 1698. [CrossRef]

11. Parisi, C.; Ronzon, T. A global View of Bio-Based Industries: Benchmarking and Monitoring Their Economic Importance and Future Developments. 2016. Available online: http:/ / publications.jrc.ec.europa.eu/repository/bitstream/JRC103038/lb-na-2837 6-en-n.pdf (accessed on 30 August 2019).

12. EC (European Commission). Jobs and Wealth in the EU Bioeconomy/JRC-Bioeconomics. 2018. Available online: https: / / ec.europa.eu/knowledge4policy/dataset/7d7d5481-2d02-4b36-8e79-697b04fa4278_en (accessed on 24 July 2019).

13. Li, Q.; Zhao, Q.; Hu, Y.; Wang, H. Biotechnology and bioeconomy in China. Biotech. J. Healthc. Nutr. Tech. 2006, 1, 1205-1214. [CrossRef]

14. Langeveld, J.W.A. Results of the JRC-SCAR Bioeconomy Survey. 2015. Available online: https://www.scar-swg-sbgb.eu/lw_ resource/datapool/_items/item_24/survey_bioeconomy_report1501_full_text.pdf (accessed on 2 October 2019).

15. Meyer, R. Bioeconomy strategies: Contexts, visions, guiding implementation principles and resulting debates. Sustainability 2017, 9, 1031. [CrossRef]

16. Gronvall, G.K. Maintaining US leadership in emerging biotechnologies to grow the economy of the future. Health Secur. 2017, 15, 31-32. [CrossRef] 
17. Staffas, L.; Gustavsson, M.; McCormick, K. Strategies and policies for the bioeconomy and bio-based economy: An analysis of official national approaches. Sustainability 2013, 5, 2751-2769. [CrossRef]

18. de Besi, M.; McCormick, K. Towards a bioeconomy in Europe: National, regional and industrial strategies. Sustainability 2015, 7, 10461-10478. [CrossRef]

19. McCormick, K.; Kautto, N. The bioeconomy in Europe: An overview. Sustainability 2013, 5, 2589-2608. [CrossRef]

20. Trigo, E.J.; Henry, G.; Sanders, J.; Schurr, U.; Ingelbrecht, I.; Revel, C.; Santana, C.; Rocha, P. Towards Bioeconomy Development in Latin America and the Caribbean. Bioeconomy Working Paper. 2013. Available online: https://agritrop.cirad.fr/567934/1 / document_567934.pdf (accessed on 31 January 2021).

21. Barbier, E.B.; Aylward, B.A. Capturing the pharmaceutical value of biodiversity in a developing country. Environ. Resour. Econ. 1996, 8, 157-181. [CrossRef]

22. Simpson, R.D.; Sedjo, R.A.; Reid, J.W. Valuing biodiversity for use in pharmaceutical research. J. Pol. Econ. 1996, 104, 163-185. [CrossRef]

23. Perrings, C.; Baumgärtner, S.; Brock, W.A.; Chopra, K.; Conte, M.; Costello, C.; Duraiappah, A.; Kinzig, A.P.; Pascual, U.; Polasky, S.; et al. Biodiversity, Ecosystem Functioning, and Human Wellbeing: An Ecological and Economic Perspective; Oxford University Press: Oxford, UK, 2009.

24. Sedjo, R.A. Preserving biodiversity as a resource. In Global Development and the Environment; Darmstadter, J., Ed.; Routledge: Abingdon, UK, 2016; pp. 99-108.

25. Ivshina, I.B.; Kuyukina, M.S. Specialized microbial resource centers: A driving force of the growing bioeconomy. In Microbial Resource Conservation; Sharma, S.K., Varma, A., Eds.; Springer: Cham, Switzerland, 2018; pp. 111-139.

26. Sasson, A.; Malpica, C. Bioeconomy in Latin America. New Biotechnol. 2018, 40, 40-45. [CrossRef] [PubMed]

27. Valli, M.; Russo, H.M.; Bolzani, V.S. The potential contribution of the natural products from Brazilian biodiversity to bioeconomy. An. Acad. Bras. Ciências 2018, 90, 763-778. [CrossRef]

28. Mateo, N.; Nader, W.; Tamayo, G. Bioprospecting. Encycl. Biodivers. 2001, 1, 471-488.

29. Healy, B. Investing in the Bioeconomy; Presented Before the Greater Baltimore Committee and the Greater Baltimore Venture Capital Group; 21 October 1992. Available online: https:/ / oculus.nlm.nih.gov/cgi/f/ findaid / findaid-idx?c=nlmfindaid;idno=10160026 5; view =reslist;didno=101600265; subview=standard;focusrgn=C02;cc=nlmfindaid;byte=43814314 (accessed on 1 November 2019).

30. Healy, B. NIH: The Modern Wonder Well Spring of the Biological Revolution Biomedicine, and the Bioeconomy; Presented at The City Club Forum; 15 May 1992. Available online: https:/ / oculus.nlm.nih.gov / cgi/f/findaid/findaid-idx?c=nlmfindaid;idno=101600 265view $=$ reslist; didno=101600265; subview $=$ standard;focusrgn $=C 02 ; c c=$ nlmfindaid;byte $=43814314$ (accessed on 1 November 2019).

31. Nerlich, B. The Bioeconomy in the News (Or Not); University of Nottingham: Nottingham, UK, 30 April 2015. Available online: http:/ /blogs.nottingham.ac.uk/makingsciencepublic/2015/04/30/the-bioeconomy-in-the-news-or-not (accessed on 6 October 2019).

32. Healy, B. On light and worth: Lessons from medicine. Vassar Q. 1994, 90, 10-13.

33. Maciejczak, M.; Hofreiter, K. How to define bioeconomy. Rocz. Nauk. Ser. 2013, 15, 243-248.

34. Petersen, A.; Krisjansen, I. Assembling "the bioeconomy": Exploiting the power of the promissory life sciences. J. Sociol. 2015, 51, 28-46. [CrossRef]

35. Von Braun, J. Science and technology policy to harmonize biologization of economies with food security. In The Fight Against Hunger and Malnutrition: The Role of Food, Agriculture, and Targeted Policies; Sahn, D.E., Ed.; Oxford University Press: Oxford, UK, 2015; pp. 240-262.

36. von Hauff, M.; Gottwald, F.T.; Stöckl, K.; Kurz, J.; Böker, C. Towards sustainable economies. In Global Stability through Decentralization? In Search for the Right Balance Between Central and Decentral Solutions; Wilderer, P.A., Grambow, M., Eds.; Springer: Cham, Switzerland, 2016; pp. 117-138.

37. Enríquez, J. Genomics and the world's economy. Science 1998, 281, 925-926. [CrossRef] [PubMed]

38. Schimmelpfennig, D.E.; Pray, C.E.; Brennan, M.F. The impact of seed industry concentration on innovation: A study of U.S. biotech market leaders. Agric. Econ. 2004, 30, 157-167. [CrossRef]

39. Bonny, S. Taking stock of the genetically modified seed sector worldwide: Market, stakeholders, and prices. Food Secur. 2014, 6, 525-540. [CrossRef]

40. Maisashvili, A.; Bryant, H.; Raulston, J.M.; Knapek, G.; Outlaw, J.; Richardson, J. Seed prices, proposed mergers and acquisitions among biotech firms. Choices 2016, 31, 1-11.

41. Howard, P.H. Intellectual property and consolidation in the seed industry. Crop Sci. 2015, 55, 2489-2495. [CrossRef]

42. Deconinck, K. New evidence on concentration in seed markets. Glob. Food Secur. 2019, 23, 135-138. [CrossRef]

43. Le Feuvre, P. Transport Biofuels-Tracking Clean Energy Progress. 2019. Available online: https://www.iea.org/tcep/transport/ biofuels (accessed on 12 October 2019).

44. NRC (National Research Council). A New Biology for the 21st Century; National Academies Press: Washington, DC, USA, 2009.

45. Orszag, P.R.; Holdren, J.P. Memorandum for the Heads of Executive Departments and Agencies, Subject: Science and Technology Priorities for the FY 2012 Budget. 21 July 2010. Available online: https: / / www.whitehouse.gov/sites/whitehouse.gov/files/ omb/memoranda/2010/m10-30.pdf (accessed on 25 April 2020). 
46. U.S. Department of Agriculture. Farm Services Agency. Biomass Crop Assistance Program. Available online: https://www.fsa. usda.gov/programs-and-services/energy-programs/BCAP/index (accessed on 25 April 2020).

47. U.S. Department of Agriculture. Biorefinery, Renewable Chemical, and Biobased Product Manufacturing Assistance Program. Available online: https:/ / www.rd.usda.gov/programs-services/biorefinery-renewable-chemical-and-biobased-productmanufacturing-assistance (accessed on 25 April 2020).

48. U.S. Department of Agriculture (USDA). What Is Biopreferred? About the BioPreferred®Program. Available online: https: //www.biopreferred.gov/BioPreferred/faces/pages/AboutBioPreferred.xhtml (accessed on 25 April 2020).

49. White House. Precision Medicine Initiative; White House: Washington, DC, USA, 2015. Available online: https: / / obamawhitehouse. archives.gov/precision-medicine (accessed on 25 April 2020).

50. Brandt, C.C.; Davis, M.R.; Davison, B.; Eaton, L.M.; Efroymson, R.A.; Hilliard, M.R.; Kline, K.; Langholtz, M.H.; Myers, A.; Shahabaddine, S.; et al. 2016 Billion-Ton Report: Advancing Domestic Resources for a Thriving Bioeconomy, Volume 1: Economic Availability of Feedstocks; Oak Ridge National Lab: Oak Ridge, TN, USA, 2016; Volume 1. [CrossRef]

51. Rogers, J.N.; Stokes, B.; Dunn, J.; Cai, H.; Wu, M.; Haq, Z.; Baumes, H. An assessment of the potential products and economic and environmental impacts resulting from a billion ton bioeconomy. Biof. Bioprod. Bioref. 2017, 11, 110-128. [CrossRef]

52. USDOE (US Department of Energy). Agile Biofoundary: How We Got Here. Available online: https://agilebiofoundry.org/howwe-got-here (accessed on 25 April 2020).

53. US National Science Foundation. Understanding the Rules of Life. Available online: https://www.nsf.gov/news/special_ reports/big_ideas/life.jsp (accessed on 25 April 2020).

54. EOP (Executive Office of the President). Modernizing the Regulatory System for Biotechnology Products: An Update to the Coordinated Framework for the Regulation of Biotechnology. 2017. Available online: https:/ / obamawhitehouse.archives.gov / sites/default/files/microsites/ostp/2017_coordinated_framework_update.pdf (accessed on 25 April 2020).

55. USDA (U.S Department of Agriculture). Report to the President of the United States from the Task Force on Agriculture and Rural Prosperity. 2017. Available online: https://www.usda.gov/sites/default/files/documents/rural-prosperityreport.pdf (accessed on 25 April 2020).

56. Pacific Northwest National Laboratory. PNNL and LanzaTech Team to Make New Jet Fuel: Virgin Atlantic to Fly First Commercial Flight on Recycled Waste Gas. Available online: https:/ /www.pnnl.gov/news/release.aspx?id=4527 (accessed on 25 April 2020).

57. BRDB (Biomass Research and Development Board). The Bioeconomy Initiative: Implementation Framework. 2019. Available online: https://biomassboard.gov/pdfs/Bioeconomy_Initiative_Implementation_FrameworkFINAL.pdf (accessed on 25 April 2020).

58. EBRC (Engineering Biology Research Consortium). Engineering Biology: A Research Roadmap for the Next Generation Bioeconomy. 2019. Available online: https:/ / roadmap.ebrc.org (accessed on 25 April 2020).

59. US Office of Management and Budget. Fiscal Year 2021 Administration Research and Development Budget Priorities. Available online: https: / / www.whitehouse.gov/wp-content/uploads/2019/08/FY-21-RD-Budget-Priorities.pdf (accessed on 31 January 2021).

60. Office of Science and Technology Policy (OSTP). Request for Information on the Bioeconomy. Federal Register. 2019. Available online: https: / www.federalregister.gov/documents/2019/09/10/2019-19470/request-for-information-on-the-bioeconomy (accessed on 31 January 2021).

61. Advancing America's Global Leadership in Science and Technology-Trump Administration Highlights: 2017-2020. Available online: https:/ /www.whitehouse.gov/wp-content/uploads/2019/10/Summary-of-White-House-Summit-on-AmericasBioeconomy-October-2019.pdf (accessed on 31 January 2021).

62. Engineering Biology Research and Development Act of 2019. Available online: https:/ /www.congress.gov/bill/116th-congress/ house-bill/4373/text (accessed on 31 January 2021).

63. Bioeconomy Research and Development Act of 2020. Available online: https://www.rubio.senate.gov/public/_cache/files/7c0 f99d0-d06b-475e-9a14-21751c4b1111/1D59A6C84BAFB03B448DA8FF556EB4B1.bioeconomy.pdf (accessed on 31 January 2021).

64. NASEM (National Academies of Sciences, Engineering, and Medicine). Industrialization of Biology: A Roadmap to Accelerate the Advanced Manufacturing of Chemicals; The National Academies Press: Washington, DC, USA, 2015.

65. NASEM (National Academies of Sciences, Engineering, and Medicine). Genetically Engineered Crops: Experiences and Prospects; The National Academies Press: Washington, DC, USA, 2016.

66. NASEM (National Academies of Sciences, Engineering, and Medicine). Preparing for Future Products of Biotechnology; The National Academies Press: Washington, DC, USA, 2017.

67. NASEM (National Academies of Sciences, Engineering, and Medicine). Biodefense in the Age of Synthetic Biology; The National Academies Press: Washington, DC, USA, 2018.

68. NASEM (National Academies of Sciences, Engineering, and Medicine). Gaseous Carbon Waste Streams Utilization: Status and Research Needs; The National Academies Press: Washington, DC, USA, 2019.

69. Scordato, L.; Bugge, M.; Fevolden, A.M. Directionality across diversity: Governing contending policy rationales in the transition towards the bioeconomy. Sustainability 2017, 9, 206. [CrossRef]

70. Pfau, S.; Hagens, J.; Dankbaar, B.; Smits, A. Visions of sustainability in bioeconomy research. Sustainability 2014, 6, 1222-1249. [CrossRef] 
71. D'Amato, D.; Droste, N.; Allen, B.; Kettunen, M.; Lähtinen, K.; Korhonen, J.; Leskinene, P.; Matthies, B.D.; Toppinen, A. Green, circular, bio economy: A comparative analysis of sustainability avenues. J. Clean Prod. 2017, 168, 716-734. [CrossRef]

72. Devaney, L.; Henchion, M. Consensus, caveats and conditions: International learnings for bioeconomy development. J. Clean Prod. 2018, 174, 1400-1411. [CrossRef]

73. Wreford, A.; Bayne, K.; Edwards, P.; Renwick, A. Enabling a transformation to a bioeconomy in New Zealand. Environ. Innov. Soc. Trans. 2019, 31, 184-199. [CrossRef]

74. Carlson, R. Estimating the biotech sector's contribution to the U.S. economy. Nat. Biotech. 2016, 34, 247-255. [CrossRef] [PubMed]

75. Bioindustrial Innovation Canada. Canada's Bioeconomy Strategy: Leveraging Our Strengths for a Sustainable Future. 2018. Available online: https:/ /docs.wixstatic.com/ugd/b22338_1906a509c5c44870a6391f4bde54a7b1.pdf (accessed on 25 April 2020).

76. Germany Bioecon. A Country Strategy for a Sustainable Bioeconomy Baden-Württemberg (English translation). 2019. Available online: https://stm.baden-wuerttemberg.de/fileadmin/redaktion/m-mlr/intern/dateien/PDFs/Bio\%C3\%B6konomie/ Landesstrategie_Nachhaltige_Bio\%C3\%B6konomie.pdf (accessed on 19 October 2019). (In German).

77. Koide, J. New Biotech Policy Contributing to Bioeconomy Bioindustry Division, Ministry of Economy, Trade and Industry (METI), Japan. Available online: https:/ / www.nedo.go.jp/content/100890873.pdf (accessed on 31 January 2021).

78. HM Government. Growing the Bioeconomy. Improving Lives and Strengthening Our Economy: A National Bioeconomy Strategy to 2030. 2019. Available online: https:/ / assets.publishing.service.gov.uk/government/uploads/system/uploads/attachment_ data/file/761856/181205_BEIS_Growing_the_Bioeconomy_Web_SP_pdf (accessed on 30 August 2019).

79. BioteCanada. The Canadian Blueprint: Beyond Moose E Mountains. How We Can Build the World's Leading Bio-Based Economy; BioteCanada: Ottawa, ON, Canada, 2009.

80. Lee, D. Bio-based economies in Asia: Economic analysis of development of bio-based industry in China, India, Japan, Korea, Malaysia and Taiwan. Int. J. Hydrog. Energy 2016, 41, 4333-4346. [CrossRef]

81. OECD (Organisation for Economic Co-Operation and Development). Meeting Policy Challenges for a Sustainable Bioeconomy; OECD Publishing: Paris, France, 2018.

82. GMO Answers. GMOs Globally. Available online: https://gmoanswers.com/gmos-globally (accessed on 30 August 2019).

83. Dubois, O.; Gomez San Juan, M. How Sustainability is Addressed in Official Bioeconomy Strategies at International, National and Regional Levels: An Overview; Environment and Natural Resources Management Working Paper 63; 2016; Available online: http:/ / www.fao.org/3/a-i5998e.pdf (accessed on 30 August 2019).

84. Ehrenfeld, W.; Kropfhäußer, F. Plant-based bioeconomy in Central Germany-A mapping of actors, industries and places. Tech. Anal. Strat. Manag. 2017, 29, 514-527. [CrossRef]

85. Statistics Sweden. The Bioeconomy_Developing New Regional Statistics. Environmental accounts MIR 2018:4. 2018. Available online: https: / / www.scb.se/contentassets / 89b174d9a3784532a1552c42330a446b/mi1301_2016a01_br_mi71br1804.pdf (accessed on 19 October 2019).

86. Juma, C.; Konde, V. Industrial and Environmental Applications of Biotechnology; United Nations Conference on Trade and Development: Geneva, Switzerland, 2001.

87. Pellerin, W.; Taylor, D.W. Measuring the biobased economy: A Canadian perspective. Ind. Biotech. 2008, 4, 363-366. [CrossRef]

88. Matyushenko, I.; Sviatukha, I.; Grigorova-Berenda, L. Modern approaches to classification of biotechnology as a part of NBICtechnologies for bioeconomy. J. Econ. Manag. Trade 2016, 14, 1-14. [CrossRef]

89. Golden, J.S.; Handfield, R.B.; Daystar, J.; McConnell, T.E. An Economic Impact Analysis of the U.S. Biobased Products Industry: A Report to the Congress of the United States of America. 2015. Available online: https:/ /www.biopreferred.gov/BPResources/ files/EconomicReport_6_12_2015.pdf (accessed on 30 August 2019).

90. Daystar, J.; Handfield, R.; Golden, J.S.; McConnell, E.; Morrison, B.; Robinson, R.; Kanaoka, K. An Economic Impact Analysis of the U.S. Biobased Products Industry. 2018. Available online: https://www.biopreferred.gov/BPResources/files/ BiobasedProductsEconomicAnalysis2018.pdf (accessed on 14 October 2019).

91. Carus, M.; Dammer, L. The circular bioeconomy-concepts, opportunities, and limitations. Ind. Biotech. 2018, 14. [CrossRef]

92. Reime, M.; Røste, A.; Coenen, L. The circular Bioeconomy in Scandinavia. 2016. Available online: http:/ / www.susvaluewaste. no/wp-content/uploads/2016/06/SusValueWaste-2016-The-circularbioeconomy-in-Scandinavia.pdf (accessed on 25 July 2019).

93. Philp, J.; Winickoff, D. Realising the Circular Bioeconomy; OECD Publishing: Paris, France, 2018.

94. Huffman, W.E.; Evenson, R.E. The effects of R\&D on farm size, specialization, and productivity. Ind. Policy Agric. Glob. Econ. 1993, 12, 41-72.

95. Soejarto, D.D.; Farnsworth, N.R. Tropical rain forests: Potential source of new drugs? Persp. Biol. Med. 1989, 32, 244-256. [CrossRef]

96. Frisvold, G.; Day-Rubenstein, K. Bioprospecting and biodiversity what happen when discoveries are made. Ariz. Law Rev. 2008, $50,545-576$.

97. Sparks, T.C.; Hahn, D.R.; Garizi, N.V. Natural products, their derivatives, mimics and synthetic equivalents: Role in agrochemical discovery. Pest Manag. Sci. 2016, 73, 700-715. [CrossRef] [PubMed]

98. Naman, C.B.; Leber, C.A.; Gerwick, W.H. Modern Natural Products Drug Discovery and Its Relevance to Biodiversity Conservation. Available online: http://labs.biology.ucsd.edu/schroeder/bggn227/Natural_Products_Biodiversity_Conservation_ Chapter_Preprint-2.pdf (accessed on 30 August 2019). 
99. Gepts, P. Who owns biodiversity, and how should the owners be compensated? Plant Phys 2004, 134, 1295-1307. [CrossRef] [PubMed]

100. Lewin, H.A.; Robinson, G.E.; Kress, W.J.; Baker, W.J.; Coddington, J.; Crandall, K.A.; Durbin, R.; Edwards, S.V.; Forest, F.; Gilbert, M.T.P.; et al. Earth BioGenome Project: Sequencing life for the future of life. Proc. Natl. Acad. Sci. USA 2018, 115, 4325-4333. [CrossRef]

101. Arujanan, M.; Singaram, M. The biotechnology and bioeconomy landscape in Malaysia. New Biotechnol. 2018, 40, 52-59. [CrossRef]

102. Ronzon, T.; Piotrowski, S.; M’Barek, R.; Carus, M. A systematic approach to understanding and quantifying the EU's bioeconomy. Bio-Based Appl. Econ. J. 2017, 6, 1-17.

103. Lier, M.; Aarne, M.; Kärkkäinen, L.; Korhonen, K.T.; Yli-Viikari, A.; Packalen, T. Synthesis on Bioeconomy Monitoring Systems in the EU Member States: Indicators for Monitoring the Progress of Bioeconomy. 2018. Available online: https://jukuri.luke.fi/ handle/10024/542249 (accessed on 30 August 2019).

104. Ronzon, T.; M’Barek, R. Socioeconomic indicators to monitor the EU's bioeconomy in transition. Sustainability 2018, $10,1745$. [CrossRef]

105. De Avillez, R. Measuring the Contribution of Modern Biotechnology to the Canadian Economy (No. 2011-18). 2011. Available online: http:/ / www.csls.ca/reports/csls2011-18.pdf (accessed on 19 October 2019).

106. Ernst and Young. The Economic Contributions of the Biotechnology Industry to the U.S. Economy. 2000. Available online: http:/ / bei.jcu.cz/Bioeconomy\%20folders/documents/bioeconomy/the-economic-contributions-of-the-biotechnologyindustry-to-the-u-s-economy (accessed on 19 October 2019).

107. Hevesi, A.; Bleiwas, K. The Economic Impact of the Biotechnology and Pharmaceutical Industries in New York; Office of the State Comptroller: New York, NY, USA, 2005.

108. Carlson, R. How Big is the Bioeconomy? Nat. Biotechnol. 2014, 32, 598. Available online: https://www.nature.com/articles/nbt. 2966 (accessed on 25 April 2020).

109. Loizou, E.; Jurga, P.; Rozakis, S.; Faber, A. Assessing the potentials of bioeconomy sectors in Poland employing input-output modeling. Sustainability 2019, 11, 594. [CrossRef]

110. Mainar Causapé, A.J.; Philippidis, G.; Sanjuán López, A.I. Analysis of Structural Patterns in Highly Disaggregated Bioeconomy Sectors by EU Member States Using SAM/IO Multipliers. JRC Technical Reports, EUR 28591; Publications Office of the European Union: Luxembourg, 2017.

111. Natural Resources Institute Finland. The Principles for Monitoring the Bioeconomy. 2019. Available online: https://www.luke. fi/wp-content/uploads/2018/11/22102018-principles-for-monitoring-eng-1.pdf (accessed on 25 April 2020).

112. Philippidis, G.; Sanjuán, A.I.; Ferrari, E.; M'barek, R. Employing social accounting matrix multipliers to profile the bioeconomy in the EU member states: Is there a structural pattern? Span. J. Agric. Res. 2014, 12, 14. [CrossRef]

113. Philippidis, G.; M'barek, R.; Ferrari, E. Drivers of the European Bioeconomy in Transition (BioEconomy2030): An Exploratory, Model-Based Assessment. 2016. Available online: https://ec.europa.eu/jrc/en/publication/eur-scientific-and-technicalresearch-reports / drivers-european-bioeconomy-transition-bioeconomy2030-exploratory-model-based-assessment (accessed on 30 August 2019).

114. Smeets, E.M.W.; Tsiropoulos, Y.; Patel, M.; Hetemäki, L.; Bringezu, S.; Banse, M.A.H.; Junker, F.; Nowicki, P.; van Leeuwen, M.G.A.; Verburg, P. The Relationship Between Bioeconomy Sectors and the Rest of the Economy; Working paper D1.1; Wageningen University \& Research: Wageningen, The Netherlands, 2013.

115. Wen, X.; Quacoe, D.; Quacoe, D.; Appiah, K.; Danso, B.A. Analysis on bioeconomy's contribution to GDP: Evidence from Japan. Sustainability 2019, 11, 712. [CrossRef]

116. NASEM (National Academies of Sciences, Engineering, and Medicine). Forest Health and Biotechnology: Possibilities and Considerations; The National Academies Press: Washington, DC, USA, 2019.

117. Kunjapur, A. An introduction to start-ups in synthetic biology. In PLOS Synbio Community; 8 September 2015. Available online: https:/ / blogs.plos.org/synbio/2015/09/08/an-introduction-to-start-ups-in-synthetic-biology (accessed on 30 August 2019).

118. CB Insights. Grapeless Wine and Cowless Milk: 60+ Synthetic Biology Startups in a Market Map. 2017. Available online: https:/ / www.cbinsights.com/research/synthetic-biology-startup-market-map/ (accessed on 25 April 2020).

119. Brodwin, E.; Bendix, A. The startup behind Silicon Valley's favorite "bleeding" veggie burger has scored a major victory in its battle for legitimacy. In Business Insider; 1 August 2019. Available online: https:/ / www.businessinsider.com/impossible-foodsbleeding-veggie-burger-ingredient-gets-fda-green-light-2018-7 (accessed on 30 August 2019).

120. Bloch, S. AquaAdvantage, the first GMO salmon, is coming to America. In The New Food Economy; 11 March 2019; Available online: https://thecounter.org/fda-aquabounty-gmo-salmon-seafood-restriction-market (accessed on 25 April 2019).

121. Ledford, H. Gene-edited animal creators look beyond U.S. market. Nature 2019, 566, 433-435. [CrossRef] [PubMed]

122. Akst, J. Genetically engineered hornless dairy calves. In The Scientist; 10 May 2016; Available online: https:/ / www.the-scientist. com/the-nutshell/genetically-engineered-hornless-dairy-calves-33553 (accessed on 30 August 2019).

123. Burwood-Taylor, L. French insect farming startup Ynsect raises $\$ 125 \mathrm{~m}$ Series C breaking European agtech record. AFN. 20 February 2019. Available online: https: / / agfundernews.com/breaking-french-insect-farming-startup-ynsect-raises-125m-seriesc-breaking-european-agtech-record.html (accessed on 30 August 2019). 
124. Zhang, S. Genetically Modified Moths Come to New York: A Diamondback Moth with Altered DNA is Being Tested to Control Pests on Cabbages. 2017. Available online: https:/ /www.theatlantic.com/science/archive/2017/09/genetically-modified-sterile-insectstake-flight/539040 (accessed on 30 August 2019).

125. Saavoss, M. How Might Cellular Agriculture Impact the Livestock, Dairy, and Poultry Industries? Choices 2019, 34. Available online: http:/ / www.choicesmagazine.org/choices-magazine/submitted-articles/how-might-cellular-agriculture-impact-thelivestock-dairy-and-poultry-industries (accessed on 25 April 2020).

126. Durham, E. First-Ever Noninvasive Mind-Controlled Robotic Arm. 2019. Available online: https://engineering.cmu.edu/newsevents/news/2019/06/20-he-sci-robotics.html (accessed on 30 August 2019).

127. Biebl, H.; Menzel, K.; Zeng, A.P.; Deckwer, W.D. Microbial production of 1,3-propanediol. Appl. Microbiol. Biotech 1999, 52, 289-297. [CrossRef] [PubMed]

128. DuPont Tate \& Lyle BioProducts. DuPont Tate \& Lyle Bio Products Begin Bio-PDOTM Production in Tennessee. 2006. Available online: http:/ /www.duponttateandlyle.com/news_112706 (accessed on 2 October 2019).

129. Furman, J.L.; Stern, S. Climbing atop the shoulders of giants: The impact of institutions on cumulative research. Am. Econ. Rev. 2011, 101, 1933-1963. [CrossRef]

130. Wierny, M.; Coremberg, A.; Costa, R.; Trigo, E.; Regúnaga, M. Measuring the Bioeconomy: Quantifying the Argentine Case; Grupo Bioeconomia: Buenos Aires, Argentina, 2015.

131. Kardung, M.; Costenoble, O.; Dammer, L.; Delahaye, R.; Lovrić, M.; van Leeuwen, M.; M’Barek, R.; van Meijl, H.; Piotrowski, S.; Ronzon, T. Framework for Measuring the Size and Development of the Bioeconomy. In BioMonitor Deliverable; 2019. Available online: http:/ /biomonitor.eu/wp-content/uploads/2020/04/Deliverable-1.1.pdf (accessed on 11 January 2021).

132. Philp, J.; Winickoff, D. Innovation Ecosystems in the Bioeconomy. 2019. OECD Science, Technology and Industry Policy Papers, No. 76; OECD Publishing: Paris, France, 2019. [CrossRef]

133. 21st Century Nanotechnology Research and Development Act .Enacted. Public Law 108-153 108th Congress. 2003. Available online: https: / www.congress.gov/bill/108th-congress/senate-bill/189 (accessed on 11 January 2021). 